
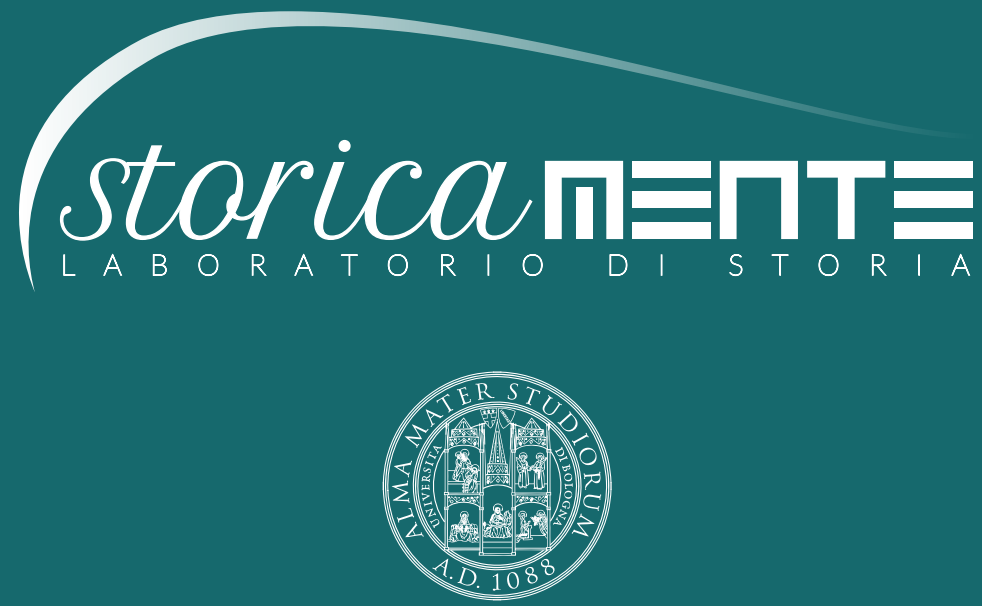

ALMA MATER STUDIORUM

Università di Bologna

Dipartimento di Storia Culture Civiltà

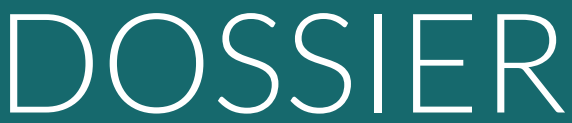

Representations of Fear in History

Empirical / Practical evidence and Methodological Issues 


\section{STORICAMENTE.ORG}

\section{Laboratorio di Storia}

Matthias Müller

Daily Routines under Constant Surveillance. West German Foreign Correspondents in Moscow in the 1950s and 60s

Numero $11-2015$

ISSN: 1825-411X

Art. 22

pp. 1-19

DOI: $10.12977 /$ stor608

Editore: BraDypUS

Data di pubblicazione: 05/02/2016

Licenza: CC BY-NC-ND 4.0 International

Articolo sottoposto a revisione paritaria a doppio cieco

Dossier: Representations of Fear in History: Empirical / Practical evidence and Methodological Issues edited by Vito Gironda, Marica Tolomelli 


\title{
Daily Routines under Constant Surveillance. West German Foreign Correspondents in Moscow in the 1950s and 60s
}

\author{
MATTHIAS MÜLLER \\ Univ. Bielefeld \\ Fakultät für Geschichtswissenschaft, Philosophie und \\ Theologie
}

The essay focuses on West German foreign-correspondents in the USSR in the post-Stalin era of the 1950s and early 1960s and their efforts to create a normal perspective on the antagonist within the Cold War. Not only the obtaining of information but also the journalists' private life was influenced by the constant control and surveillance of Soviet authorities and the special living conditions in Moscow. The correspondents assessed and managed these measures in different ways due to their differing biographical backgrounds and professional experience. In fact, these measures gave the journalists a view of the authorities' impact on Soviet society, in Moscow and the rural areas as well.

\section{Introduction}

In his seminal study about the organisation of newspapers, Walter Hagemann stated that «the best are just good enough" [Hagemann 1950, 92] to practice the profession of a foreign correspondent, not only because of the inter-cultural requirements, but because of the correspondents influence on their homeland's perspective on other countries. The West German public's view on the USSR in the 1950s was, because of historical and contemporary political issues a special one indeed. And the correspondents' work in Moscow also was. 


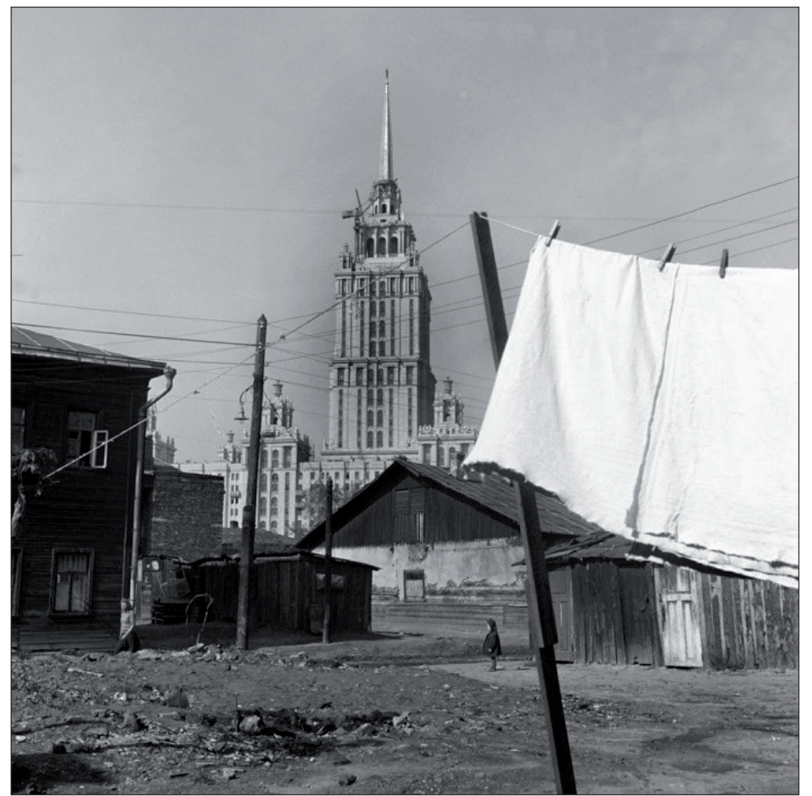

One city, two worlds. The Hotel "Ukraina" in the late 1950s, the residence of Western correspondents, Photo by Peter BockSchröder.
After a short outlining of Soviet-West German relations in 1950s and especially the debates on and images of 'Russia' in the West German society, the text focuses on five journalists in Moscow from the mid-1950s to the mid 1960s. Initially, for a better understanding of their professional and personal experience within the media-system and the Russian society, the biographical backgrounds of the journalists are portrayed. Following this, the correspondents' living conditions in Moscow, their daily working routine, the information procurement and the contact to other medial players are drawn. In the last step the impact of measures from the Soviet authorities on the journalists daily life and work is shown up, especially the constant surveillance and censorship'. Relating to this, it is also asked how the correspondents perceived and assessed these measures. Foreign correspondents are the subject of historical works only for a short while, referring to this lack of (historical) scientific works about this group of media players, the essay analyses especially contemporary autobiographical writings of the correspondents and in addition re-

1 The terms 'Foreign Correspondent', 'Correspondent' and 'Journalist' are used equally. 
cords from the archives of the Westdeutscher Rundfunk (WDR) which was the only broadcasting station of the West German broadcasting corporation $A R D$ with an own constant Moscow correspondent in the 1950s and 1960s.

\section{German-soviet relations between fear and nostalgic roman- tics}

With the establishment of constant diplomatic relations and the release of the last German prisoners of war in 1955, the relationship between the Federal Republic and the Soviet Union started to normalize. Nevertheless, the social and political situation in the USSR during the 1950s remained vague for the majority of West German society [Laak 2010, 24-27]. Opposite to the public debate about the 'free world' in the west, the discussion on Russia and the Soviet Union (the terms were mostly used equally) was emotionally charged and produced an inconsistent mixture of different historical, cultural and political issues. On the one hand western politicians and media drew a constant scenario of intimidation through Soviet politics and their armed forces. In this context the phraseology reached from ironical terms of the Weimar period up to aggressive anti-Bolshevist rhetoric from propaganda of the Third Reich [Aycoberry 2001, 467]. This negative portrait was intensified by the narratives of former German soldiers returning from the Siberian POW camps [Hilger 2008, 78-81]. On the other hand, the public debate was minted by the classical apotheosis of Russia and its culture based on 19th century's writers like Leo Tolstoy. The fear of a Russian invasion and a mixture of socialist barbarism and disastrous living conditions clashed with the romantic portrait of a large countryside and beautiful landscapes, distilled in the german term "Weites Land» [Schewe 1968, 8-10]. Because of the intended integration of the Federal Republic into the west, this confusion about the living conditions in 
the USSR was for most West German officials more useful then problematic [Laak 2010, 25]. At least during the Berlin-Blockade in 1949 the USSR confirmed the image as an aggressor from the East, the majority of West German citizens now convicted the foreign policy of the Soviet government and favoured the partnership with the Western Allies [Wende 2007, 65]. But nevertheless, the general interest in Soviet society grew, the book Der Sowjetmensch, written by the historian and journalist Klaus Mehnert was published in 1958 already in its fourth edition [Mehnert 1958]. For Mehnert, it was a vocational and personal aim to clarify the indistinct situation in the USSR for the West German media public and to create an objective coverage about the Cold War antagonist [Mehnert 1988, 318].

The first-hand involvement of West German media actors in the Soviet Union followed not until the mid 1950s with the visit of chancellor Konrad Adenauer in Moscow in September 1955, this incidence led to the above mentioned constant diplomatic relations between the Federal Republic and the USSR [Altenrichter 2007]. At this moment, the West German media were confronted for the first time immediately with the Soviet Union after World War II. In addition to Adenauer's official delegation, eighty-seven West German journalists moved to Moscow to report about this major diplomatic issue, it was the beginning of a straight coverage from Russia by West German Media [Rüden 2004, 119].

\section{Biographical Backgrounds}

The first German long-time foreign correspondent in Moscow was Hermann Pörzgen. Born in 1905 in Kiel, Pörzgen studied theatre arts in Hamburg, Riga, Berlin and Cologne. Afterwards he began his international journalist activities for the Frankfurter Zeitung in Switzerland, Italy and the Balkans between 1929 and 1935. He worked in Ea- 
stern Europe, first Prague, then Warsaw and finally Moscow in 1937. Pörzgen stayed in the Soviet capital until the declaration of war in 1941. In fact, Pörzgen was the only West German correspondent in the USSR after the war who had worked directly for the Nazi regime. As a party member of the NSDAP, Pörzgen wrote for the Frankfurter Zeitung, the party organ Das Reich and served as a press attaché in Berlin, Casablanca, Paris and Sofia, where he was arrested by the Red Army in 1944 [Auswärtiges Amt 2008, 502f]. After ten years of war captivity in the USSR, Pörzgen was released in October 1955 and he continued his journalistic career for the Frankfurter Allgemeine Zeitung (FAZ) immediately. Only six months later he returned as a foreign correspondent to Moscow where he stayed until his death in 1976 [Jahn 2005, 812]. Pörzgen acted as the spokesman of the West German correspondents and became one of the leading experts for Soviet society and politics and culture in the 1950s and 60s [Drommert 1972].

For the West German broadcasting media, the first correspondent right after the Adenauer-visit in Moscow was the already mentioned Klaus Mehnert, like Pörzgen a veteran and early expert for Eastern Europe and Russia. Born in Moscow in 1906, Mehnert and his family returned to their homeland Germany in the 1920s where he studied history in Tübingen and Berlin before finishing his studies in to Berkeley. Mehnert received his PhD in 1932 and worked for Deutscher Akademischer Austauschdienst in Berlin and the journal Osteuropa, between 1934 and 1936 he was the Moscow correspondent for several German newspapers. Until 1946, Mehnert held professorships in Honolulu, Berkeley and Shanghai. In 1946 he returned to Germany and served as chief editor for Christ und Welt and Osteuropa until the 1970s. Mehnert joined the Adenauer-delegation in 1955 and stayed in Moscow for only seven months, reporting for the Süddeutscher Rundfunk (SR) [Mehnert 1988, 321-22]. Following this short interlude, he continued working for the SR, Deutschlandfunk and Zweites Deutsches Fernsehen (ZDF). During his journalistic and scientific career, Mehnert wrote several pu- 
blications about the Russian and Soviet society and the international consequences of Soviet foreign policy².

In contrast to Pörzgen and Mehnert, the first long-time broadcastjournalist for West German media was a rookie. Born in 1928 in Hamburg, Gerd Ruge abandoned his university studies in history and economics to attend a class at the newly founded broadcasting school of Nordwestdeutscher Rundfunk (NWDR) in 1949 [Schwarzkopf 2007, 21]. Following his graduation, Ruge worked as an editor for the NWDR and became the first West German correspondent in Belgrade in 1950, only aged twenty-two. Following a short-term occupation as a war correspondent in Korea, Ruge joined the Adenauer-delegation to Moscow in 1955. One year later, the director-general of the newly founded WDR Hans Hartmann who was one of Ruge's sponsors, appointed Ruge as the only West German broadcasting-correspondent in the Eastern Bloc. Ruge stayed in Moscow for three years until 1959 [Thiemeyer 2005, 102; Katz 2006, 18, 29]. In addition to his reports for the WDR, Ruge also wrote articles for several West German newspapers, especially Die Zeit ${ }^{3}$. In the following years Ruge became one of the leading players of West German news-making. After establishing new radio and TV formats for the WDR as its chief editor, Ruge worked in Bonn, Washington D.C. and Beijing in the 1960s and 70s and returned to Moscow in 1987 where he stayed for another six years [Mangold 2013].

His successor in 1959 was like Ruge himself one of the younger journalists that started their career after World War II. Erwin Behrens, born in 1928 in Duisburg, commenced his studies at a journalist school in Aachen in 1947 and continued together with Ruge at the broadcasting-school of the NWDR in Hamburg [Schwarzkopf 2007,

\section{2 http://www.deutsche-biographie.de/pnd118579959.html}

3 HA WDR, 4139, Letter from broadcasting-director Fritz Brühl to director-general Hans Hartmann, 09/12/1957. 
21]. Subsequently Behrens worked for the NWDR in Cologne between 1949 and 1954 as a political editor and for the station's broadcasting branch from 1955 onwards until he became correspondent in Moscow in 1959. Schewe stayed there for six years at last and moved like Ruge to the United States in 1965 where he reported from the United Nations [Schwarzkopf 2007, 21].

Another press correspondent was Heinz Schewe, born in 1921 in Hagen. After his final exams Schewe was conscripted into the Reichsarbeitsdienst, during World War II he served as a radio operator in the German Luftwaffe. Deployed at the Eastern Front, Schewe was in contact to collaborators and downed Russian pilots and gained knowledge in the Russian language. Following the war, Schewe worked as a translator for the British military administration in North Germany and became a professional interpreter for the Hamburg based newspaper Die Welt in 1949 after having finished his studies in linguistics. Without journalistic experience, Schewe became the paper's London correspondent and worked for the desk 'foreign reports' in the midfifties [Schewe 1976, 116-18; 149-50]. Between 1958 and 1967 Schewe reported from Moscow notably for Die Welt and other publications of the Springer media group. Subsequently, he continued his journalistic career in Jerusalem, Prague, Vienna and Tel Aviv ${ }^{4}$.

In addition to the regular reports and articles, each correspondent wrote at least one book about the social and political developments in the USSR and personal impressions of living and working in Moscow. In this way the journalists influenced and formed the perspective on the Soviet Union in West German media on a long-term basis significantly. Apart from this, for the younger correspondents the work in Moscow was the first big step in their international news-making career.

4 http://www.lwl.org/literaturkommission/alex/index. php?id=00000017\&layout $=2 \&$ author $\_i d=00001578 \& k e y=$ Schewe 


\section{Daily life and information procurement}

The major aspect of the correspondents' activity was (and is up to date) to gather information. While their colleagues in West European countries and the United States were overwhelmed by hundreds off different newspaper articles and several press conferences a week, the work of West German correspondents in Moscow was also deeply influenced by the Soviet media system [Jürgens 1974, 37-38]. The daily routine was therefore dominated by reading and analysing. Schewe and Pörzgen pointed out that the correspondents received up to thirty newspapers and magazines a day and both of them stressed the importance of a constant and long-time press reception [Pörzgen 1972, 182; Schewe 1968, 13]. But in fact, Schewe described especially the CPSU-Newspaper Pravda as containing primarily «boring statistics» [Schewe 1968, 13], Pörzgen criticised the newspaper's monotony as well [Pörzgen 1958, 133]. Other magazines presented mostly trivial stories or anecdotes of everyday life [Pörzgen 1972, 182]. Political decision making, poverty, the supply situation and further central social aspects were completely absent. Pörzgen underlines that the contents of Russian media were only useful for obtaining information if the reader knew the overall context, long term developments and was able to read between the lines consequently [Pörzgen 1972, 182]. Similar to the newspapers, the news agency TASS focused on governmental positions, radio and television programmes reported mostly everyday life stories [Behrens 1968, 176]. To cut a long story short, the Soviet media offered the correspondents only information matching to governmental positions, omitting critics or contradictions. In 1963 the Novosti was founded as a special department of TASS, it delivered especially information and material to western broadcasting and television journalists ${ }^{5}$. This special service was an example for the 'care' of the Soviet autho-

5 HA WDR, 13504, Letter from chief-editor Franz Wördemann to broadcastingdirector Hans-Joachim Lange, 01/29/1963. 
rities to the western journalists, indeed it enabled the authorities to influence the coverage of western media directly. Aside the analysis or rather interpretation of media contents, the face-to-face communication with political officials was another potential source of information for the western correspondents. Exclusive interviews were nearly impossible, the encounters with officials happened mostly at receptions at Western European embassies or the foreign ministry. Those meetings between correspondents and high-ranking politicians were described by Pörzgen and Ruge in their writings as mostly amicable but superficial [Pörzgen 1958, 121; Ruge 1958, 122-124]. To get information about the 'real' country and everyday life, the journalists had to talk to the ordinary people, but owing to governmental surveillance, the possibilities of gaining authentic impressions were indeed very small. Fearing restrictions of the authorities, most conversations in everyday encounters with waitresses or salesmen for example, were like the talks to the officials amicable but cursory [Ruge 1958c, 27, 31, 46-49].

Apart from their interviewees' aloofness, the problems of gaining information was also influenced by the geographical situation of the western correspondents main work. Pörzgen, Ruge and their colleagues from Western Europe initially resided in the Hotel National and from 1957 onwards in the tremendous Hotel Ukraina, part of the Stalinist architectural program Seven Sisters. Most of the western correspondents had no detached workspace at their own, the journalists used their apartments as their office, the West German ARD got an own office not until 1968. The boundary of working life and private life was fluid [Katz 2006, 85-86], the financial resources were low, neither the press-journalists nor the broadcast-journalists had an own staff, Erwin Behrens got an office assistant not until $1962^{6}$. Because of this, the correspondents' wives acted as their assistants, which underlines the fusion

6 HA WDR, 13504, Letter from chief-editor Franz Wördemann to broadcastingdirector Hans-Joachim Lange, 01/29/1963. 
of working and private life on another level. And like their husbands, the wives' activities were observed by the authorities as well [MüllerMarein 1959].

These living and working conditions in and around the Ukraina created a kind of insular world for the West German correspondents and their colleagues within the Soviet capital [Mangold 2013]. It is noticeable, that both in the correspondents autobiographical publications and in the correspondence with their superiors these colleagues remained a nameless crowd, which according to Pörzgen consisted of approximately seventy persons at the end of the 1950s [Pörzgen 1958, 150]. Pörzgen himself profited from his good connections to other longtime correspondents, reaching back into the inter-war period. With the staff members of western embassies, as Pörzgen describes it, he was «in touch» $[1972,182]$. His most important contact was the friendship to the US-american correspondent Henry Shapiro. Like Pörzgen, Shapiro was a veteran in Moscow, working there from 1933 onwards? Now, as the head of United Press he was one of the central figures in the western coverage from the USSR and well connected to the Soviet officials. Pörzgen, who characterized himself and Shapiro as the «doyens» [180] in the group of western journalists, met several times a week with his colleague and friend to discuss political and social developments, exchange information and new sources [182-83]. In the 1960s, Erwin Behrens cooperated with the Moscow correspondent of $A B C$, Sam Jaffe, to develop a practicable way for the production and exports of television pictures. The $A B C$ had already granted a permission to film in 1960 and Ruge, now correspondent in Washington DC, suggested to Schewe and his superiors to purchase $A B C$-made films and to merge them with an own produced spoken text. First of all, this measure was less expensive then producing own pictures. However,

7 http://www.nytimes.com/1991/04/09/obituaries/henry-shapiro-84-longtimereporter-in-moscow-for-upi.html 
the more important reason was the fact, that it was nearly impossible to grant an own permission to film by the authorities. The cooperation with Jaffe and Shapiro was not an exception, with other western correspondents the West German journalists stayed in regular contact to share new sources and topics and because of the special situation within the Ukraina district, the group of western journalists developed a kind of esprit de corps. Compared to their colleagues in the western world, the competition on sources and exclusive interviewees was secondary to the general lack of information due to governmental restrictions [183-85]. The East German correspondents are not mentioned by the journalists, neither in their writings nor in the correspondence with their superiors, the contact to local journalists is drawn only superficially. According to Pörzgen and Ruge, the Russian journalists had no exclusive information from political insiders, their coverage was mainly based on governmental communiques. Unlike their colleagues from West Germany, France or the United Kingdom who got additional information from their homelands, the Russian journalists did not have extensive access to western news agencies. Therefore, the western correspondents had in parts more multiple sources then their Russian colleagues themselves [184]. Pörzgen described the relation to the Russian journalists as "collegial» and "friendly» but underlines in the same passage that his eastern colleagues in general acted very cautiously and that they had "of course» [184] no interest in an intensive information exchange. Like the 'ordinary' people in Moscow, in Pörzgen's view his Russian colleagues feared regulatory restrictions.

Actually, the special conditions of living and working included another problem, known as correspondents' syndrome [Jürgens 1974, 38-41]. The daily routine of long-time foreign correspondents implied the risk of losing an objective view on their country and that their perso-

8 HA WDR, 13504, Letter from chief-editor Franz Wördemann to broadcastingdirector Hans-Joachim Lange, 01/29/1963. 
nal experience and observations could be generalized. In addition, the idea of acting as a kind of journalistic 'ambassador' could suppress the observing function of the correspondents, political views and prevailing stereotypes showed up in their coverage [39-40]. Moreover, from the correspondents view, the technically journalistic work was not the defining element of their profession, but the constant interacting with and exploring of their environment which was necessary to understand the 'real' country from which they reported. This notably was a way do distinguish themselves from other journalists, especially short-time correspondents, in media studies called parachuters [Hess 1996, 17-18]. Because of their isolation in the Ukraina district, the correspondents could almost not achieve this ambition of an objective and extensive perspective on the USSR.

\section{Everyday surveillance in and outside Moscow}

The inhabitants of the hotel's district beside the correspondents and their families consisted mainly of diplomats and other western political officials, the schools and supermarkets in the nearby area let the correspondents live in pleasant inhabitant conditions [Katz 2006, 8586]. However, this referred to a circumscribed area for everyday life activities which could be easily controlled by the authorities, in a 2013 interview, Ruge summarized that some of his colleagues perceived the whole country as a "prison» [Mangold 2013]. Especially the communication between the journalists and their colleagues and superiors in West Germany was under permanent surveillance. The written reports for the editors were controlled and bowdlerized by officials and agents in the telegraph office. Although the journalists were able to transmit their reports to their editorial offices by telephone, most of the calls were wire taped by intelligence and interrupted in single cases [Rüden $2004,120]$. As a result, the only and rare possibility, to send volatile or 
unexpurgated material to the editorial team in Germany, was to give it unofficially to western diplomats just before their departures. Not only the correspondents work but also their private lives where under surveillance, Ruge who described the observation in parts as "primitive» [Mangold 2013], was followed by two agents of the security agency KGB permanently and in his hotel room the authorities controlled him by regular phone calls [Mangold 2013].

These were the daily routines within the Ukraina district. Especially Ruge described the additional correspondents' dependence on the authorities, if the journalists wanted to leave the capital. Ironically, as Ruge writes, it was Nikita Khrushchev himself at a banquet at the foreign ministry, who asked the western journalists to travel along the countryside, to discover the 'real' Russian people [Ruge 1958c, 175]. But (of course), for research and travels outside Moscow, the journalist needed also an agreement of the authorities, this process lasted from a few days up to several weeks. Spontaneous, short dated researches were nearly impossible and the authorities predetermined the travelling routes. Ruge's travel to Siberia in 1957 was organised by the governmentrun travel-agency Intourist, the travelling routes, flights and transport by car, train or bus were predefined in most cases. On the one hand, this was another example for the government's 'care' for the western journalists. On the other hand, those well-ordered journeys gave the officials the possibility, to control the correspondents movements outside Moscow in detail [1958c, 271-73]. Ruge had to register at the local authorities, if he was not attended by officials at the airports or stations directly. These officials attended Ruge at his local stops, occasionally paid his bills in the restaurants and influenced his research, by presenting him for example outstanding historical buildings and in contrast new factories, schools or other features of the different locations. This underlined the intention of the authorities, to present the unity of historical, technological and cultural achievements of the Soviet society and to prevent negative impressions on a West German journalists and 
in consequence to the readers and listeners in his homeland [272, 290]. From Ruge's point of view, the officials intended to avoid any situations that could lead to a negative coverage. Like in Moscow, Ruge was not able to talk to ordinary people without being accompanied by a public official or the local soviet. The officials encroached in the talks between Ruge and the people, if the interviewees criticized the supply situation or social politics and their impact on everyday life in general or, the other way around, accused the foreign policy of the western countries or German war crimes during World War II [Ruge 1958c, 306, 324-25]. In general, Ruge described the talks in parts as naive, the statements and reactions of his interviewees usually replicated official governmental positions [324-26]. Ruge and Schewe both assessed the behaviour of the officials and the ordinary people as a kind of universal mistrust against persons from the West, not western journalists in particular [Ruge 1958c, 307-308; Schewe 1968, 11-12]. But, as a positive effect and an implicit journalistic success, Ruge and his colleagues got an impression of the scope and implementation of governmental structures within the rural areas and he emphasized his treatment by the local officials as less complicated and more honest then in Moscow [Ruge 1958c, 190-93, 268]. These travels around the country outside Moscow became standardised in the following years. While Ruge travelled mostly alone and with an individual program, his successor Erwin Behrens reported about a journey to the Black Sea in the early 1960s which was organised by the government for a group of fifteen correspondents from Western Europe and the United States [Behrens 1964, 167-169]. Again, the movements and at last the coverage of the correspondents could be controlled by the authorities easily.

One of the few possibilities to obtain exclusive and critical information was the contact with actors from the cultural scene, notably opponent authors. These meetings contained a political and journalistic risk indeed. Due to the opponents special status, the correspondents were pulled into internal Soviet matters. Ruge was banned from inter- 
viewing members of Union of Soviet Writers in 1958, after some writers had given critical statements about governmental decisions and social issues in conversations with him [Ruge 1958c, 155]. A very special case was the relation to Nobel prize winning author Boris Pasternak, Ruge visited him in his house outside Moscow several times. Ruge and Schewe each wrote a book about Pasternak, his work and his opposition against the CPSU [Ruge 1958b; Schewe 1964]. Retrospectively, Ruge described those meetings not only with sympathy but enthusiasm for the international awarded, in his home country repudiated author of Doctor Zhivago. In his contemporary and retrospective writings Ruge mentions that Pasternak's attitude and resistance against the Soviet government motivated and inspired him to carry on with his journalistic work [Ruge 1958a, 1958b; Mangold 2013]. This was of course a very romantic and glorifying perspective, although this case shows up how the special working and living conditions in Moscow influenced the correspondents' perspective and reduced the journalists' objectivity. The permanent surveillance and control by the authorities was indeed disruptive and inconvenient, but in fact, the West German journalists in the 1950s and 1960s were not directly punished by the Soviet authorities. Ruge was having problems to get an accreditation for his reentry in 1958, in his point of view a wilful dalliance of the authorities. However, this was more or less a standardised measure and demonstration of power against western players and not specific for the treatment of Ruge himself because of an individual inappropriate behaviour 9 . The correspondents themselves handled and assessed the authorial measures slightly different. In general, the manners of the Soviet government were recognized and described as disruptive and annoying - but not threatening. Pörzgen underlined the improved living conditions in Moscow as well for the population in general and for the

9 HA WDR, 4139, Letter from Gerd Ruge to director-general Hans Hartmann, 10/29/1958. 
correspondents in particular and Mehnert even praised the authorities as behaving "courteous» [Mehnert 1988, 322] towards the western journalists. In contrast, Ruge criticized the intervention of the authorities several times, especially referring to his meetings with the opponent authors. These subjective assessments can be partially explained by the journalists biographical background and their personal experience. Pörzgen and Mehnert appraised the acting of the authorities in comparison to the governmental measures in the Stalin era of the mid1930s. Facing to that, the treatment of opponents, non-governmental critical press agents and western players in general was improved and 'courteous' indeed. In his contemporary writings Pörzgen gave a detailed, in single passages a romantically oversubscribed description of the Moscow journalistic and diplomatic society in the 1950s [1958]. The most interesting fact at this point was, that Pörzgen and his colleagues neither in their autobiographical writings nor in the correspondence with the editors and their superiors portrayed the Soviet Union and its government as the 'enemy' within the Cold War in an explicit way [Pörzgen 1972; Ruge 1958; Schewe 1968]. Certainly, the constant presence of the surveillance apparatus influenced the correspondents private and working life. Schewe stated in 1968 about his experience with the measures of the authorities in Moscow that «the fear of being under steady surveillance» could lead to "delusions» of "sensitive characters among the foreigners in Moscow» [Schewe 1968, 10]. These quotes show up, how Schewe assessed the situation of the western journalists. From his point of view for the constant correspondents, who were no longer 'foreigners' in Moscow the surveillance became more or less 'normal' after some time and they integrated the authorial measures in their daily working routine increasingly. In the same passage, he wrote about an unnamed colleague, who "turned the radio louder» and "pulled the telephone between the bedsheets» when he was receiving visitors. Schewe criticised that behaviour as «exaggerated» and concluded «somebody like this should not go to Moscow» [11]. 


\section{Summary}

Wire taped phone calls, secret agents in everyday situations and nearly no contact to 'ordinary' Russians. In comparison to their colleagues in western countries, the work and life of West German correspondents in Moscow was determined and controlled by their environment in multiple ways. First of all, the correspondents reported from the enemy's territory within the Cold War, with the personal aim to objectify the West German fearful view on the USSR, which was veiled through a mixture of Cold War-propaganda, anti-Bolshevist ideas from the Third Reich and romantic-nostalgic impressions. But actually, the correspondents had no extensive opportunities to discover the country and the society in an objective way. While the authorities controlled most of their activities and approaches in and outside Moscow, the informal conversations between the correspondents and 'ordinary' people stayed cautios but superficial. The public officials distrusted the western journalists and tried to avoid a negative coverage about the USSR on the one hand, an insight and an interference in internal Soviet affairs by the journalists on the other hand. The 'care' of the authorities and the living conditions were, based on their different biographical backgrounds, perceived and assessed by the correspondents slightly different. Influenced by a permanent scenario of surveillance, the correspondents had to integrate these authorial measures in their personal and professional life, which was, due to the living conditions in the district of the Hotel Ukraina and the correspondents' demands on their profession as 24/7-observers nearly the same anyhow. In spite of the frustration over the limited diversity, quantity and quality of their coverage, the correspondents adjusted their everyday work to the external conditions in the Soviet Capital. For the journalists, the surveillance was annoying and incriminating but, after a certain time, a regular part of their daily routine. 


\section{References}

Auswärtiges Amt (ed.) 2008, Biographisches Handbuch des deutschen Auswärtigen Dienstes. 1871-1945, Paderborn: Schöningh.

Aycoberry P. 2001, Der Bolschewikm, in: Etienne F., Schulze H. (eds.), Deutsche Erinnerungsorte, Munich: Beck: 455-468.

Behrens E. 1964, Tagebuch aus Moskau, Hamburg: Wegner.

Drommert R. 1972, Ein großartiger Kenner der Sowjetunion, «Die Zeit», 50, December 15.

Hagemann W. 1950, Die Zeitung als Organismus, Münster: Oldenbourg.

Hess S. 1996, International news \& foreign correspondents, Washington DC: Brookings Institution Press.

Hilger A. 2008, Das Rußlandbild der deutschen Kriegsheimkehrer, "Forum für osteuropäische Ideen- und Zeitgeschichte», 12 (1): 65-83.

Jarausch K., Siegrist H. (eds.) 1997, Amerikanisierung und Sowjetisierung in Deutschland 1945-1970, Frankfurt, New York: Steiner.

Jürgens G. 1974, Politische Auslandsberichterstattung im deutschen Fernsehen. Am Beispiel der Korrespondentenberichterstattung über die USA, Berlin: Fachbereich Politische Wissenschaft der Freien Universität Berlin.

Katz K. (ed.) 2006, Am Puls der Zeit. Der Sender: Weltweit nah dran 1956-1985 / 50 Jahre WDR, Vol. 2, Cologne: Kiepenheuer \& Witsch.

Kilian W. 2005, Adenauers Reise nach Moskau, Freiburg im Breisgau: Herder.

Laak D. van 2010, Das Bild der Sowjetunion in Deutschland nach 1945, in: Fischer C. (ed.), Russische Literatur als deutsch-deutscher Brückenschlag (1945-1990), Jena: Inst. für Slawistik der Friedrich-Schiller-Universität, 18-34.

Mangold I. 2013, "Viele meiner Kollegen waren regelrecht verbittert". Der Journalist und Publizist Gerd Ruge, "Zeitmagazin», 34.

Mehnert K. 1958, Der Sowjetmensch. Versuch eines Porträts nach dreizehn Reisen in die Sowjetunion 1929-1959, Reinbek: Rowohlt.

- 1988, Ein Deutscher in der Welt: Erinnerungen 1906-1981, Frankfurt am Main: Fischer.

Müller-Marein J. 1959, Durfte Chruschtschow lächeln?, «Die Zeit», 34, August 21.

Pörzgen H. 1958, So lebt man in Moskau, Munich: List.

- 1972, 100mal Sowjetunion, Munich: Piper.

Rüden P. von 2004, "Ich habe immer versucht, die historische Erklärdimension in der journalistischen Arbeit nicht zu vernachlässigen". Interview mit Gerd Ruge, "Rundfunk und Geschichte - Mitteilungen des Studienkreises Rundfunk und Geschichte», 30: 
$116-126$.

Ruge G. 1958a, Begegnung mit dem anderen Rußland, «Die Zeit», 3, January 16.

- 1958b, Boris Pasternak. Russlands großer Dichter, «Die Zeit», 42, October 16.

- 1958c, Gespräche in Moskau, Cologne: Kiepenheuer \& Witsch.

- 1958d, Pasternak. Eine Bildbiografie, Munich: Kindler.

Schewe H. 1968, Berichte aus Moskau, Frankfurt am Main: Ullstein.

- 1974, Pasternak privat, Hamburg: Christians.

Thiemeyer G. 2005, 'Wandel durch Annäherrung'. Westdeutsche Journalisten in Osteuropa 1956-1977, "Archiv für Sozialgeschichte», 45: 101-117.

Wende W. 2007, Beschützer kritisiert man nicht - oder vielleicht doch? Zum Bild Amerikas in der westdeutschen Publizistik der späten 1940er und 1950er Jahre in: Koch L. (ed.), Modernisierung als Amerikanisierung? Entwicklungslinien der westdeutschen Kultur 1945-1960, 63-89, Bielefeld: Transcript.

\section{List of abbreviations}

ABC: American Broadcasting Company

ARD: Arbeitsgemeinschaft der öffentlich-rechtlichen Rundfunkanstalten der Bundesrepublik Deutschland

CPSU: Communist Party of the Soviet Union

HA WDR: Historisches Archiv des WDR, Cologne

NWDR: Nordwestdeutscher Rundfunk

SR: Süddeutscher Rundfunk

TASS: Telegrafnoje agentstwo Sowjetskogo Sojusa

WDR: Westdeutscher Rundfunk 